\title{
ANTIHYALURONIDASE STUDIES OF SERA FROM PATIENTS WITH RHEUMATIC FEVER, STREPTOCOCCAL INFECTIONS, AND MISCELLANEOUS NON-STREPTOCOCCAL DISEASES ${ }^{1}$
}

\author{
BY ROBERT W. QUINN 2 \\ (From the Section of Preventive Medicine, Yale University School of Medicine, New Haven)
}

(Received for publication December 17, 1947)

\section{INTRODUCTION}

In the previous paper the technical aspects of the mucin-clot prevention test which was standardized by McClean (1) have been described. Friou and Wenner (2) using the mucin-clot prevention test have demonstrated the clinical significance of an inhibitory substance in human serum capable of neutralizing an enzyme elaborated by a strain of hemolytic streptococcus. The amount of inhibitory substance was shown by them to be greater in the sera of patients with rheumatic fever than in patients early in the course of uncomplicated hemolytic streptococcal infections or normal individuals. A brief historical background of the work preceding that of Friou and Wenner has been presented in the previous paper.

The purpose of this paper is to report the clinical application of the mucin-clot prevention test in the determination of the antihyaluronidase titre of sera of patients with rheumatic fever, hemolytic streptococcal infections, miscellaneous other diseases, and normal individuals.

\section{MATERIALS AND METHODS}

The materials and methods used in these studies were exactly as described in the previous paper.

Enzyme: The enzyme used throughout in these tests was that produced by a strain of Group A, type 4 beta hemolytic streptococcus. Each serum was tested against a constant amount (16 units) of hyaluronidase.

Substrate: The substrate was composed of a $0.15 \%$ solution of potassium hyaluronate in distilled water, normal horse serum in a dilution of $1: 10$ in physiological saline, and distilled water in a ratio of $1: 1: 2$, respectively. Potassium hyaluronate was prepared according to the method of McClean et al. (3).

Serum: The blood used in the study of normal individuals and patients was drawn as aseptically as possible.

\footnotetext{
1 Aided by a grant from the Life Insurance Medical Research Fund.

2 Milbank Memorial Fund Fellow 1946-47.
}

The serum was separated from the clot within 24 hours in most instances and stored in lusteroid tubes at $-70^{\circ} \mathrm{C.}{ }^{3}$

Methods of determining the mean antihyaluronidase titre:

An arbitrary code was devised and numbers were assigned to each titre, e.g.:

$\begin{array}{cr}\text { Serum dilution } & \text { Code } \\ 0 & -.2 \\ 1: 16 & 1 \\ 1: 32 & 2 \\ 1: 64 & 3 \\ \text { etc. } & 4\end{array}$

An equation for determining the code was devised.4 and

$$
\text { Code }=\frac{\log \text { reciprocal titre }-.9013}{-.3010}
$$

$\log$ reciprocal titre $=(-.3010 \times$ code $)-.9031$

Example: For a serum with the antihyaluronidase titre 1: 4096 the code would be:

$$
\begin{aligned}
\text { Code } & =\frac{\log 4096-.9031}{-.3010} \\
& =\frac{3.6124-.9031}{-.3010} \\
& =\frac{-2.7093}{-.3010}=9
\end{aligned}
$$

The mean antihyaluronidase titre for a group of sera was determined by the formula below:

$$
\frac{\text { codes of sera }}{\text { number of sera }}=\text { mean code. }
$$

The titre to which the code number was arbitrarily assigned was then determined.

3 Blood specimens were collected from the wards of the New Haven Hospital and Dispensary Clinic. They also were obtained from patients at the U. S. Naval Hospital at St. Albans, Long Island, through the courtesy of Capt. H. L. Weaver and Capt. W. D. Small, from patients in the St. Francis Sanitorium for Cardiac Children at Roselyn, L. I., through the courtesy of Dr. Leo Taran and the Rev. Mother Superior, and from patients in the Children's Center, New Haven, Conn., through the assistance of Dr. C. W. Woodruff.

4 Dr. John H. Watkins, Assoc. Prof. of Public Health devised this formula and his advise was followed in determining the statistical significance of the results. 


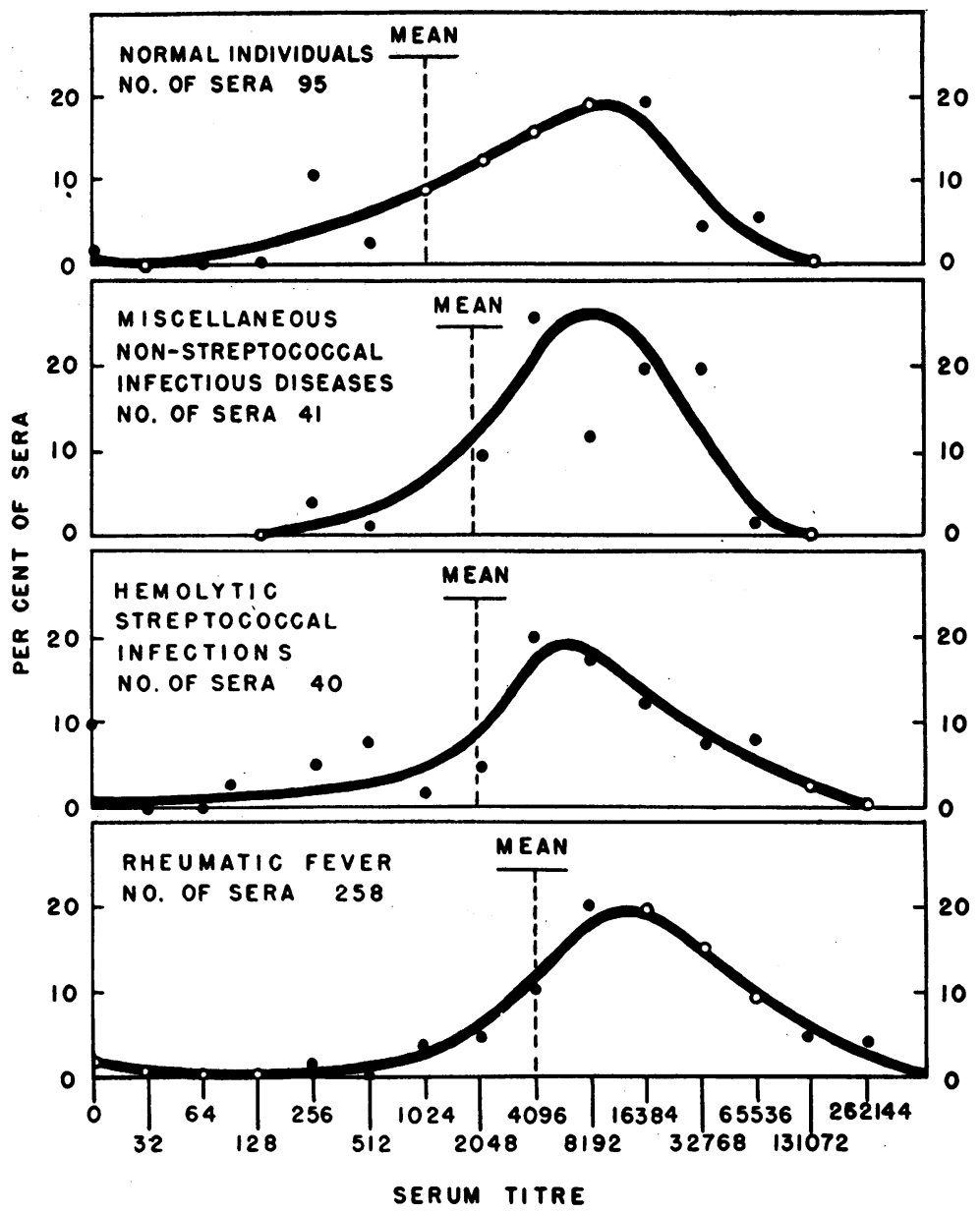

Fig. 1. Frequency Distribution of Antihyaluronidase Titres for Sera from Patients with Rheumatic Fever, Hemolytic Streptococcal Infections, Miscellaneous Non-Streptococcal Infectious DisEASES, AND NoRmal Individuals

\section{RESULTS}

A total of 495 sera from 387 individuals was tested. As a base line the mean antihyaluronidase titre of 95 normal adult sera was first determined as $1: 1024$. The mean antihyaluronidase titre of all groups of sera are recorded in Table I and Figure 1. Subsequently the mean of 40 sera from patients convalescent from scarlet fever and other acute beta hemolytic streptococcal infections was determined to be slightly less than $1: 2048$. That of ten patients with active rheumatoid arthritis was $1: 1024$. Forty-one sera from patients with nonstreptococcal infectious diseases including tuberculosis, syphilis, bacterial and "virus" pneumonia, leprosy, Vincent's angina, gonococcus urethritis, etc. had a mean titre slightly less than $1: 2048$. The mean antihyaluronidase titre for 41 sera from the patients with non-streptococcal infectious diseases combined with the ten sera from patients with rheumatoid arthritis was slightly less than $1: 2048$. Sera from all the 258 patients with rheumatic fever had a mean antihyaluronidase titre of $1: 4096$. The sera from patients with rheumatic fever were analyzed further according to the state of activity of the rheumatic process at the time the blood was collected. The mean antihyaluronidase titres for these different groups of sera were as follows: For rheumatic fever, active, acute, it was higher than $1: 16,384$ being slightly nearer to $1: 16,384$ than the next highest dilution which would be $1: 32,768$. In this group of patients 
TABLE I

Mean antihyaluronidase titre of sera from groups of patients according to diagnosis

\begin{tabular}{|c|c|c|}
\hline Diagnosis & $\begin{array}{c}\text { Number } \\
\text { of } \\
\text { sera }\end{array}$ & $\begin{array}{c}\text { Mean } \\
\text { antihyaluronidase } \\
\text { titre }\end{array}$ \\
\hline $\begin{array}{l}\text { Normal Individuals } \\
\text { Miscellaneous Non-streptococcal } \\
\text { Infectious Diseases } \\
\text { Miscellaneous Non-streptococcal } \\
\text { Infectious Diseases plus Rheumatoid } \\
\text { Arthritis } \\
\text { Rheumatoid Arthritis, Active } \\
\text { Scarlet Fever plus other Beta } \\
\text { Hemolytic Streptococcal Infections } \\
\text { Rheumatic Fever }\end{array}$ & $\begin{array}{r}95 \\
41 \\
51 \\
10 \\
40 \\
258 \\
495 \\
15 \\
83 \\
31 \\
21 \\
81\end{array}$ & $\begin{array}{c}1: 1024 \\
\text { slightly less than } \\
1: 2048 \\
\text { slightly less than } \\
1: 2048 \\
\text { slightly higher than } \\
1: 1024 \\
\text { slightly less than } \\
1: 2048 \\
1: 4096\end{array}$ \\
\hline
\end{tabular}

were those whose illness had begun within three weeks of the time the serum was collected and who still had high fever, acute arthritis, tachycardia, carditis, and other clinical and laboratory evidence of acute rheumatic fever. These patients were all receiving salicylates by mouth in therapeutic doses. The highest individual antihyaluronidase titres were observed in this group of patients. The titre of some sera in this group was as high as $1: 262$,144 and furthermore this high titre was not observed in sera from any individuals other than those with rheumatic fever, active, acute. The mean titre for the group with rheumatic fever, active, i.e., those whose illness was more than three weeks old but who still had evidence of ac- tivity as manifested by fever, tachycardia, carditis, rapid sedimentation rate, electrocardiographic changes, etc., was midway between 1:4096 and 1: 8192. The group with active but subsiding rheumatic fever had a mean antienzyme titre slightly higher than $1: 8192$. About one fourth of the patients with active, or active, subsiding rheumatic fever were receiving salicylates. The mean titre of the sera from patients whose illness was classified as rheumatic fever, active, chronic, was midway between $1: 2048$ and $1: 4096$. These patients had been ill with low-grade, active rheumatic fever for many months. Two were receiving salicylates. The mean antihyaluronidase titre for sera from patients with inactive rheumatic fever was slightly higher than $1: 2048$.

In the statistical analysis of the differences between the mean antihyaluronidase titres of groups of sera, the $t$ test (4) was employed. Values of $t$ of 1.96 or greater were interpreted to mean that the differences between the mean titres of the two groups of sera under comparison were statistically significant.

The mean antihyaluronidase titre of sera from rheumatic fever patients of $1: 4096$ was significantly higher than the mean titre of sera from any other group of patients or from normal individuals. These comparisons are recorded in Table II along with the computed standard difference, the standard error of difference and the value of $t$. The frequency distribution of the antihyaluronidase titres of sera from each group of patients is plotted in Figure 1. This figure shows graphically the

TABLE II

Statistical analysis of the differences between the mean titres of groups of sera

\begin{tabular}{|c|c|c|c|c|c|}
\hline \multicolumn{2}{|c|}{ Number of sera being compared } & $\begin{array}{l}\text { Standard } \\
\text { difference }\end{array}$ & $\begin{array}{l}\text { Standard } \\
\text { error of } \\
\text { difference }\end{array}$ & $t$ & $\begin{array}{l}\text { Statistically } \\
\text { significant }\end{array}$ \\
\hline $\begin{array}{l}\text { Rheumatic Fever (258) } \\
\text { Rheumatic Fever (258) } \\
\text { Rheumatic Fever (258) } \\
\text { Scarlet Fever plus other Streptococcal } \\
\text { Infections (40) } \\
\text { Scarlet Fever plus other Streptococcal } \\
\text { Infections (40) } \\
\text { Miscellaneous Diseases plus Rheumatoid } \\
\text { Arthritis (51) } \\
\text { Rheumatic Fever, Active, Acute (15) } \\
\text { Rheumatic Fever, Active, Acute (15) } \\
\text { Rheumatic Fever, Active, Acute (15) } \\
\text { Rheumatic Fever, Active, Acute (15) } \\
\text { Rheumatic Fever, Active, Acute (15) } \\
\text { Rheumatic Fever, Active, Acute (15) } \\
\text { Rheumatic Fever, Active, Acute (15) }\end{array}$ & $\begin{array}{l}\text { vs. Normal Individuals (95) } \\
\text { vs. Scarlet Fever and other Beta Hemolytic } \\
\text { Streptococcal Infections (40) } \\
\text { vs. Miscellaneous Diseases plus Rheumatoid } \\
\text { Arthritis (51) } \\
\text { vs. Miscellaneous Diseases plus Rheumatoid } \\
\text { Arthritis (51) } \\
\text { vs. Normal Individuals (95) } \\
\text { vs. Normal Individuals (95) } \\
\text { vs. Normal Individuals (95) } \\
\text { vs. Miscellaneous Non-streptococcal } \\
\text { Diseases (41) } \\
\text { vs. Scarlet Fever and other Beta Hemolytic } \\
\text { Streptococcal Infections (40) } \\
\text { vs. Rheumatic Fever, Active (83) } \\
\text { Rheumatic Fever, Active, Subsiding (31) } \\
\text { Rheumatic Fever, Active, Chronic (21) } \\
\text { Rheumatic Fever, Inactive (81) }\end{array}$ & $\begin{array}{l}2.135 \\
2.330 \\
2.042 \\
2.773 \\
2.609 \\
2.093 \\
3.088 \\
0.2849 \\
2.436 \\
2.626 \\
2.1659 \\
1.911 \\
1.941\end{array}$ & $\begin{array}{l}0.256 \\
0.396 \\
0.343 \\
0.582 \\
0.492\end{array}$ & $\begin{array}{l}8.04 \\
5.95 \\
4.19 \\
1.89 \\
0.803 \\
1.94 \\
5.042 \\
3.998 \\
6.264 \\
2.35 \\
1.67 \\
13.426 \\
5.423\end{array}$ & $\begin{array}{l}\text { Yes } \\
\text { Yes } \\
\text { Yes } \\
\text { No } \\
\text { No } \\
\text { No } \\
\text { Yes } \\
\text { Yes } \\
\text { Yes } \\
\text { Yes } \\
\text { No } \\
\text { Yes } \\
\text { Yes }\end{array}$ \\
\hline
\end{tabular}




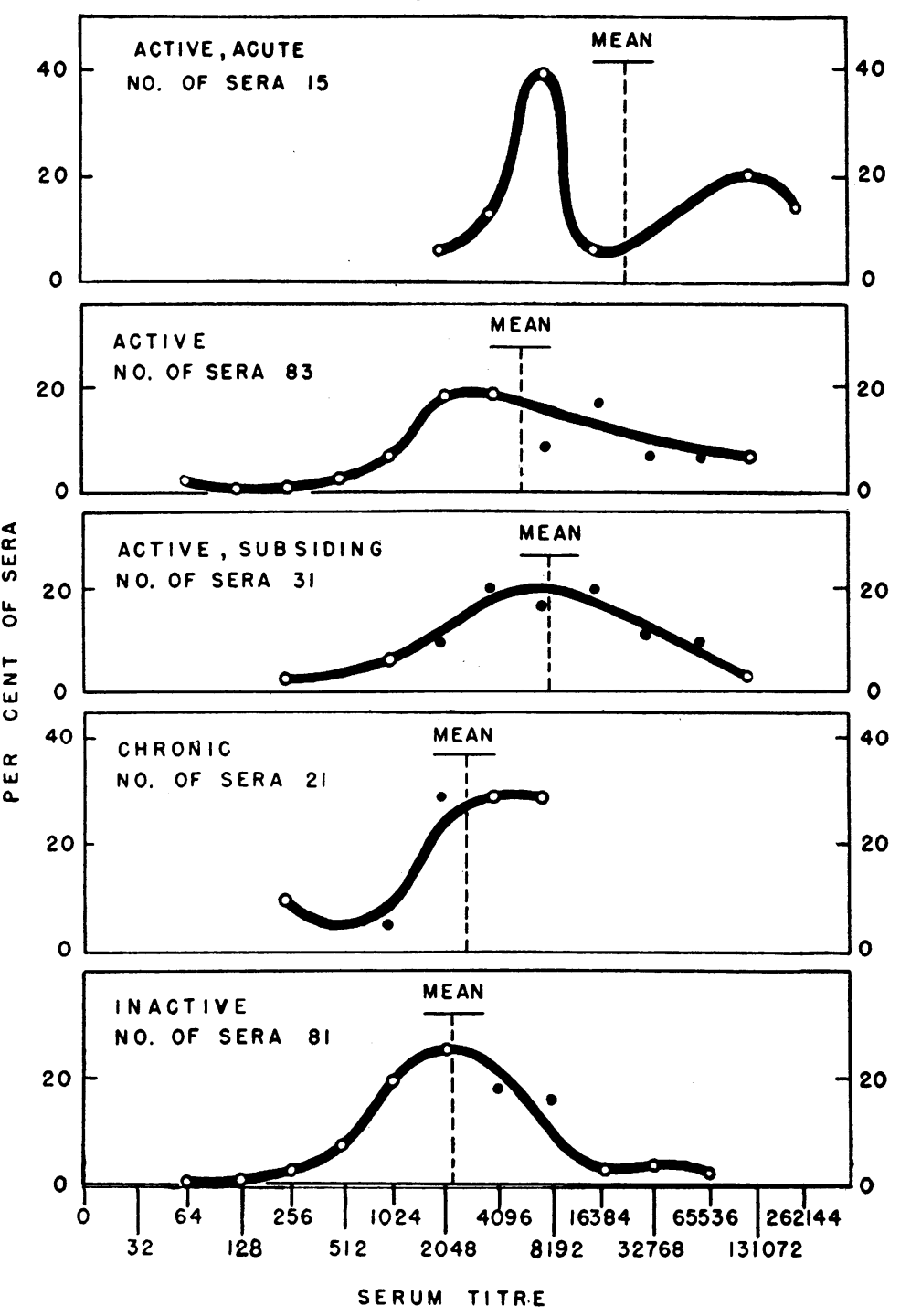

Fig. 2. Frequency Distribution of Antihyaluronidase Titres of Sera from Patients with Rheumatic Fever in Different Stages of ACTIVITY

wider range of titres and higher mean titre of the rheumatic fever sera compared with sera from patients with hemolytic streptococcal infections, non-streptococcal infectious diseases, and normal individuals.

One of the important results of these studies was the finding that the mean antihyaluronidase titre of the sera from patients with rheumatic fever, active, acute, was significantly higher than the mean titre of sera from normal individuals or from any other group of patients except those with rheumatic fever, active, subsiding. The mean titre of sera from patients with rheumatic fever, active, acute, was actually higher than the mean titre from patients with rheumatic fever active, subsiding, but the difference was not statistically significant. The mean titre of sera from patients with rheumatic fever, active, acute, however, was significantly higher than the mean titre of the sera from patients in any other phase of rheumatic fever. The frequency distribution of antihyaluronidase titres of sera from different groups of rheumatic fever patients was plotted in Table II. Here is shown the higher range of titres of sera from pa- 
tients with rheumatic fever, active, acute, and the gradual decrease in mean antihyaluronidase titre from the group, with rheumatic fever, active, acute, to the group with rheumatic fever, inactive.

\section{DISCUSSION}

In these studies the contention of Friou and Wenner (2) that the amount of inhibitory substance against streptococcal hyaluronidase in sera from patients with rheumatic fever was greater than in sera from patients early in the course of uncomplicated hemolytic streptococcal infections or from normal individuals has been confirmed. It also has been demonstrated that the serum antihyaluronidase titre in patients early in the course of active rheumatic fever is significantly higher than the antihyaluronidase titres of sera from any other group of patients studied including patients with active, subsiding, or inactive rheumatic fever, hemolytic streptococcal disease, and non-streptococcal infectious diseases. The results do not yield information which indicates that patients with streptococcal disease have a higher mean antihyaluronidase titre than patients with other infectious diseases. However, further studies of the antihyaluronidase titre in patients during the course of streptococcal infection and rheumatic fever along with the antifibrinolysin and antistreptolysin "O" titres are being done and will be reported later.

No attempt has been made to study the effect of salicylates on the antihyaluronidase titre of patients or the effect of salicylates on hyaluronidase in vivo and in vitro, but from the recent reports by Guerra (5), Pike (6), Dorfman et al. (7), and Meyer (8), it would appear that salicylates do inhibit the spreading effect of hyaluronidase in skin but have no inhibitory effect on testicular or bacterial hyaluronidase in vivo in concentrations obtained therapeutically.

Obviously much more investigation is necessary before the meaning of these results will be fully understood or before this test can be proposed as a diagnostic measure.

\section{SUMMARY AND CONCLUSIONS}

1. Studies of the determination of antihyaluronidase titres of sera from patients with rheumatic fever, hemolytic streptococcal infections, miscellaneous non-streptococcal infectious diseases, and normal individuals have been presented.

2. The mean antihyaluronidase titre of sera from patients with rheumatic fever was significantly higher than the mean titre of sera from the other groups of patients studied.

3. The mean antihyaluronidase titre of sera from patients with rheumatic fever, active, acute, was significantly higher than the mean antihyaluronidase titre of sera from patients with rheumatic fever in less active forms and from sera from patients in other groups studied.

\section{BIBLIOGRAPHY}

1. McClean, D., Studies on diffusing factors; 2. Methods of assay of hyaluronidase and their correlation with skin diffusing activity. Biochem. J., 1943, 37, 169.

2. Friou, G. J., and Wenner, H. A., On the occurrence in human serum of an inhibitory substance to hyaluronidase produced by a strain of hemolytic streptococcus. J. Infect. Dis., 1947, 80, 185.

3. McClean, D., Rogers, H. J., Williams, B. W., and Hale, C. W., Early diagnosis of wound infection, with special reference to gas-gangrene. Lancet, 1943, 1, 355.

4. Snedecor, G. S., Statistical Methods. Iowa State College Press, Ames, Iowa, 1946.

5. Guerra, F., Hyaluronidase inhibition by sodium salicylate in rheumatic fever. Science, 1946, 103, 686.

6. Pike, R. M., Failure of sodium salicylate to inhibit hyaluronidase in vitro. Science, 1947, 105, 391.

7. Dorfman, A., Reimers, E. J., and Ott, M. L., Action of sodium salicylate on hyaluronidase. Proc. Soc. Exper. Biol. \& Med., 1947, 64, 357.

8. Meyer, K., Biological significance of hyaluronic acid and hyaluronidase. Physiol. Rev., 1947, 27, 335. 